\title{
EKSISTENSI SEJARAH KEBUDAYAAN MAPPANRETASI SUKU BUGIS DIPAGATAN TANAH BUMBU TAHUN 2010-2020
}

\author{
Muhammad Rico \\ Email:2010111210027@mhs.ulm.ac.id \\ Program Studi Pendidikan Sejarah Fakultas Keguruan dan Ilmu Pendidikan \\ Universitas Lambung Mangkurat \\ Banjarmasin
}

\begin{abstract}
Abstrak
Mappanretasi (pesta laut) adalah kolaborasi tradisional yang dilakukan oleh masyarakat suku Bugis di desa Pagatan, Tanah Bumbu Kalimantan Selatan. Banyak orang berasumsi bahwa perayaan tradisional Mappanretasi adalah ritual untuk ibadah atas hasil laut, dalam pergeseran makna perayaan itu berarti berterima kasih kepada Tuhan Yang Maha Kuasa untuk bersyukur dan berterima kasih atas produksi hasil laut yang sanggat melimpah, waktu Mappanretasi digunakan sebagai makna untuk membangun relasi pertemanan antara berbagai masyarakat yang terdiri dari banyak etnis dengan yang lainnya dalam lingkungan sosial, ini ditafsirkan dalam ritual ibadah laut. Penerapan Mappanretasi masih banyak yang tidak dimengerti oleh banyak orang, memberikan sebuah persepsi negatif atas pesan esensial yang terkandung dalam perayaan tersebut. bahwa perayaan Mappanretasi sebuah pesan moral, setiap orang harus berterima kasih kepada Tuhan Yang Maha Esa atas karunia, kelimpahan rezeki, dan kesehatan atas sesuatu yang diberikan. Sebaiknya setiap orang harus menghormati bentuk dari pengetahuan lokal dan posisi sifat manusia yang tidak mengekspoitasi alam, tetapi memiliki moral tanggung jawab untuk keseimbangan alam itu sendiri penelitian ini menggunakan metode kualitatif dari hasil wawancara, dan observasi.
\end{abstract}

Kata Kunci : Eksistensi Sejarah Kebudayaan, mappanretasi, pesan moral

\section{A. PENDAHULUAN}

Budaya yang terdapat dalam suatu daerah beraneka ragam dan bervariasi. Hal tersebut disebabkan karena sifat budaya itu sendiri turun temurun dari generasi ke generasi. Budaya yang sudah diyakini sejak dulu, akan dijadikan ritual terus menerus dan bersifat sakral yang dilakukan oleh setiap generasi. Salah satunya upacara tradisional dalam masyarakat Bugis Pagatan setelah berhasil mendapatkan kesuksesan hidup biasanya akan dirayakan upacara adat Mappanretasi dalam bentuk syukuran. Mappanretasi (pesta laut) 
juga sebuah upacara adat suku Bugis yang hanya dimiliki masyarakat Pagatan Kabupaten Tanah Bumbu. Dibalik kemeriahan dan makna, wawasan Sosial sejarah kebudayaan ini.

\section{B. SEJARAH LAHIRNYA KEBUDAYAAN MAPPANRETASI}

Menurut M. Jafriansyah latar belakang diadakannya upacara adat Mappanretasi dikalangan masyarakat suku Bugis Pagatan Mappanretasi awalnya dilakukan oleh pihak keluarga Muhammad Saleh pada sekitar tahun 1850. Muhammad Saleh bermata pencaharian sebagai nelayan, pada suatu hari dia menjala di laut, namun bukan ikan yang terjala melainkan seseorang besurban putih dengan mengenakan baju dan celana berwarna kuning. Syarat pertama selalu siap menerima kedatangannya kapan saja, dan yang kedua selalu mengingat orang itu baik diwaktu senang maupun susah. Muhammad Saleh mengabulkan permintaan-permintaan tersebut dengan bantuan Wa'icu dan Pua'Daceng adik dari isteri Muhammad Saleh sendiri. Sebagai nelayan Muhammad Saleh selalu membawa pulang ikan yang banyak,akhirnya diapun menjadi saudagar yang kaya raya dan mempunyai anak buah serta beberapa buah perahu. Sejak itu, pemberian makanan atau sesajen tidak lagi hanya dilakukan oleh keluarga Muhammad Saleh,tetapi sudah melibatkan para nelayan dan pihak kerajaan Bugis Pagatan.Pemberian sesajen dilaksanakan setahun sekali, yaitu pada hari Senin bulan Sya'ban,pelaksanaannya dilakukan pada jam 06.00 Wita meninggalkan rumah menuju ke laut,dan tepat jam 08.00 Wita, maka penyerahan sesajenpun dilakukan.

\section{JENIS STRUKTURAL KEBUDAYAAN MAPPANRETASI}

Budaya Mappanretasi termasuk kedalam folklor sebagian lisan karena bentuknya merupakan komunikasi tradisional dan unsur bukan lisan, kepercayaan rakyat, adat-istiadat, upacara, dan pesta rakyat, terdiri dari pernyataan yang bersifat lisan ditambah dengan gerak isyarat yang dianggap mempunyai makna dan dapat dianggap sebagai pembawa rezeki. (Unsur bukan lisan) Mappanretasi adalah suatu kegiatan yang bersifat ritual dan dilaksanakan secara adat oleh sekelompok masyarakat nelayan Pagatan bersama pemerintah setempat dengan jalan memberikan berbagai macam makanan atau sesaji di laut. Kegiatan upacara yang bersifat tradisional tentu saja mempunyai tujuan, karena masyarakat 
yang melaksanakan upacara tersebut menginginkan suatu kehidupan yang lebih baik, dan adanya perubahan- perubahan dari tatanan kehidupan. tujuan Mappanretasi adalah agar para nelayan diberikan rezeki yang banyak dari penangkapan ikan di laut di masa yang akan datang, dan juga diberikan perlindungan dari ombak dan badai serta bahaya-bahaya dan terima kasih para nelayan kepada Tuhan Yang Maha Esa atas hasil laut yang berlimpah.

\section{PESAN MORAL YANG TERKANDUNG DALAM BUDAYA MAPPANRETASI}

Adapun pesan moral yang terkandung didalam bahan sesajen Mappanretasi, yaitu; (1) Ketan masak dalam sebuah piring memiliki pesan moral agar bertingkah laku harus sesuai dengan ajaran agama, (2) Ayam jantan dan betina dengan warna bulu yang khusus memiliki pesan moral agar manusia memberikan contoh teladan yang baik dan selalu berserah diri kepada Tuhan Yang Maha Esa, (3) Dua ekor ayam yakni satu jantan dan satu betina yang sudah dipanggang memiliki pesan moral agar manusia dalam melakukan permohonan dengan hati yang ikhlas, dan tidak mengharapkan timbal balik dari permohonannya tersebut, (4) Empat sisir pisang raja memiliki pesan moral setiap manusia pasti berkembang dan tidak mau mati sebelum berjasa, (5) Ketan masak (sokko) empat warna memiliki pesan moral agar manusia bersatu agar tidak mudah terpecah belah, (6) Empat butir telur masak memiliki pesan moral bahwa manusia selalu bisa mengatasi halangan dan rintangan dalam kehidupannya, dan (7) Bunga rampai memiliki pesan moral sebagai makhluk ciptaan Allah SWT manusia adalah makhluk yang paling mulia dan dalam kehidupannya dimasyarakat.

\section{REFERENSI}

Pajeri, Nahrul. 2010. Mappanretasi Pesta Laut. Gunung Tinggi: Pemerintah Kabupaten Tanah Bumbu Dinas Kebudayaan dan Pariwisata Makna, Pesan Moral Pesta Laut.

Batennie, Faisal. 2010. Bugis Pagatan Dan Budaya Mappanretasi Di Bumi Banua Banjar. http://faisalbatennie.blogspot.com, diakses pada 21, Agustus 2021 Jam 15.13 WITA.

Situs resmi Pesta Adat Pagatan Online dari Situs: http://www.jhonlimagz.com/mappanretasi / Situs resmi Pesan Moral Dalam Tulisan http://www.sabda.org/publikasi/e- penulis/ 177/ diakses pada Tanggal 21, Agustus 2021 Jam 15.20 WITA. 